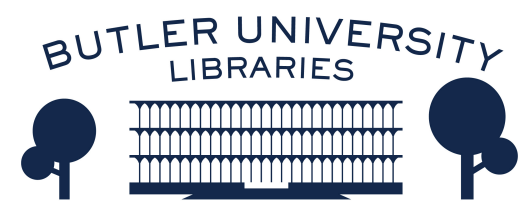

Journal of Hindu-Christian Studies

Volume 3

Article 11

January 1990

\title{
Viewpoints: Levels of Dialogue
}

Bettina Bäumer

Follow this and additional works at: https://digitalcommons.butler.edu/jhcs

Part of the Religion Commons

\section{Recommended Citation}

Bäumer, Bettina (1990) "Viewpoints: Levels of Dialogue," Journal of Hindu-Christian Studies: Vol. 3, Article 11.

Available at: https://doi.org/10.7825/2164-6279.1034

The Journal of Hindu-Christian Studies is a publication of the Society for Hindu-Christian Studies. The digital version is made available by Digital Commons @ Butler University. For questions about the Journal or the Society, please contact cbauman@butler.edu. For more information about Digital Commons @ Butler University, please contact digitalscholarship@butler.edu. 


\title{
VIEWPOINTS
}

\author{
Levels of Dialogue \\ Bettina Bäumer \\ Abhishiktananda Society \\ Varanasi, India
}

As in any human relationship, the relationship between religions is also taking place at many levels: There is the merely external physical or social meeting, which can take the form of a neutral coexistence or aggressive confrontation. Then there is the human level of living together which can produce a certain mutual understanding and acceptance. This happens naturally in any pluri-religious society, among neighbours, colleagues at work, or even within the same family as in the case of interreligious marriages. Another type of conscious dialogue takes place on the academic or intellectual level. In fact, most of what is talked and written about 'dialogue', and most of the organized dialogue-meetings belong to this intellectual level. Another kind of dialogue or meeting between Hindus and Christians is at the devotional level, like sharing of festivals, prayers and rituals. It is often assumed that this is the best and easiest contact between the two religions, because bhakti touches the heart and not only the head level. However, there is an even deeper spiritual level on which a Hindu and a Christian can meet (this type of meeting is more personal and more difficult to realize in a group). At this level it is neither the social, nor the intellectual nor the emotional dimension of religion which is in the foreground, it is rather the direct experience of Reality, transmitted by a particular religious tradition, which touches another experience ( $s \bar{a} k s \bar{a} t k \bar{a} r a)$.

Though all the levels of diàlogue are necessary and can support each other, it is this last dimension which touches the heart of the matter. First of all, can the partners in such a dialogue recognize that there is a mystical dimension in the other tradition? Any preconceived idea that the truth (in the case of Christians) or the experience (in the case of Hindus) is only with us and not with the other, will preclude any openness to accept an authentic experience in the other tradition. Once a meeting of two authentic spiritual experiences takes place, there are at least two ways of reacting to it: One will assume that at this level the experience is one, and that therefore the question of 'dialogue' is solved, since there are no longer 'two' partners, traditions, theologies, etc. The other reaction will be one of surprise at the fact that the languages, symbols and ways of these experiences are so different, though their depth-dimension is so close. To my mind, the real dialogue starts here only: After recognizing each other's authentic spiritual experience, to move from this centre to the periphery and to analyze these languages and traditions in the light of that very recognition. For example, the question of the Unity and Diversity in God, of Advaita or Trinity, of Siva-Sakti, Trika, etc., can only be fruitfully discussed at that level, for all other theological comparisons will invariably remain at the verbal and intellectual level. 


\section{Viewpoints}

I would call this kind of procedure a descending dialogue, whereas starting from the social or any other level would be an ascending way of dialogue, with the inherent danger of taking any of these levels as ultimate.

\section{In Dialogue with Hindus? My Experience and Reflections}

Sr. Vandana, Jeevan Dhara Ashram

Garhwal, Himalayas

\section{Wondrous Vistas}

Today, in our pluralistic global village, with its technological civilization, ecological disasters, socio-economic-political oppression apparently crumbling churches, and religion seemingly becoming increasingly redundant especially in the West, wondrous vistas are opened up in the spiritual world. For, I do believe, that as religions in past centuries often served to divide us, in the coming decades and century, spirituality will unite us more and more. "Indeed the hour is coming and is already here. . . when the Father will be worshipped in spirit and in truth" (John 4.2324), irrespective of religions. Today too, it is hardly possible to be a good Christian or indeed, a good follower of any faith without being conscious of and practically involved in some form of Interfaith Dialogue.

If, about twenty years ago, M. M. Thomas had said that in the transformation of every religion, the meeting with another religion plays an important part, ${ }^{1}$ today we can add that it plays an essential part in our own spiritual transformation. This is more visible and tangible in the West, where so many have been and are so greatly influenced by Eastern religions and meditation practices, that the Vatican's Congregation for the Doctrine of the Faith has even thought it fit to release a cautionary, official guidance on the subject in late 1989. Dr. Panikkar has aptly said that our neighbour's faith is part of our own religious development. To love our neighbours, he says, one must know their faith. And he adds significantly: "If we are not able to, in some way, attain the religious experience of our co-citizens, we cannot pretend to have understood their beliefs, much less presume to pass judgement on them".2 This has also been my growing conviction.

This article will be written primarily from my experiential knowledge, for Dialogue is primarily Praxis - issuing in theologizing. ${ }^{3}$

A three-fold "Guru Kripa" (Grace of the Master)

I consider this pure gift; by the grace of God; I feel so enormously enriched through my contacts with many kinds of Hindus. Here I will deal with some who were simple, saintly and scholarly. I trust that I will be forgiven if I speak mostly in the first person singular, and sometimes in the plural.

a) The "we" I may slip into will refer to my English colleague and Sr. Eeshpriya Mataji with whom I have been closely involved in this venture for the past twenty years. Her creative and extraordinarily sensitive way of listening to and learning from another culture and faith have been a pure gift of God for me. Without her, I think I 